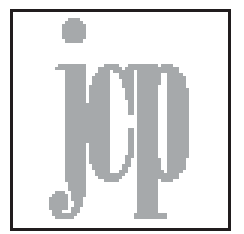

\title{
Analysing Oral Accounts of Women Survivors of 1947 Migration
}

\author{
Zarina Qasim \\ Department of English | University of Sargodha \\ zarina.qasim@uos.edu.pk
}

Asifa Qasim

Department of English | University of Lahore

\begin{abstract}
This paper analyses forty narratives by Muslim women survivors of 1947 migration from East to West Punjab. The respondents were interviewed for their most precarious experience during the migration. The narratives could be divided into three phases, i.e., pre eviction, eviction and journey phase with violence being a permanent and continuous feature of all the three phases. The narrators endured physical and psychological violence as they were attacked and massacred massively. One reason for these attacks may be that the women represent family honour in the subcontinent and therefore attacking, kidnapping or raping them means abasing the whole rival community. The paper explores the ideology behind protecting or exploiting women to safeguard or damage the honour and pride of the Muslim community by the Muslim and non-Muslim men, respectively. Finally, the women's volition for suicide and honour killing substantiate the argument that the women stood for familial and communal chastity and pride. Women's apparently passive and honour bound role bears great impact in determining the repute of their family and religious community at large.
\end{abstract}

Keywords: Migration, partition, women, violence, resistance 
The partition of British India and the subsequent migration from both sides of the border witnessed one of the world's bloodiest communal riots. These riots affected women and children the most. The migrant women's traumatic experiences of dislocation were probably more horrible than those of men's. An official estimate regarding the number of abducted girls and women was approximately 50,000 Muslims in India and 33,000 Sikhs and Hindus in Pakistan (Menon and Bhasin 18).

Various Indian historians and sociologists have conducted studies on the partition violence documenting experiences of Sikh and Hindu women but Muslim women's experiences of migration and violence remain relatively less explored. Reconstructing our knowledge of this crucial event and the consequent communal violence on the Indian side of the border is fundamental in extending the space from which explanations of female Muslim migrants' experiences may be better understood. The present study is an attempt to analyse one episode from the personal narratives of the female survivors of the 1947 migration, from East Punjab to West Punjab, to explore different forms of gendered violence targeted against Muslims. The study aims to identify different forms of violence experienced by Muslim women as a minority group at the time of 1947 partition and the subsequent migration from India to Pakistan (East to West Punjab). The study also investigates the women's response to violence in relation to their religious, communal and national identity. The data have been gathered through personal narratives of female survivors of 1947 migration to document their voices which have mostly remained unheard.

Violence against women has been studied by various scholars. Veena Das, for instance, has investigated different kinds of violence incurred on women's bodies and minds, and how they negotiate their way through the mess (68). Sonu Shiva observes that during the frenzy period of migration the women suffered the most. Men's suffering of getting uprooted or loss of assets can be overcome with the passage of time, women however suffer an unrecoverable loss, the loss of dignity which is directly connected with sexual impurity. Virdee analyses the situation stating that during the harrowing and chaotic months of August and September 1947, women underwent the most horrible crimes tantamount to what can be termed as 'femicide'. There are personal narratives of kidnapping, massive killing to save honour, mutilation and violation of women bodies, unspeakable crimes intended on hurting the 'Other' (469).

Women are viewed as the symbol of honour of an entire family and the concept of honour is tightly coupled with their sexuality. To guard the women's 
honour by strictly controlling their 'chastity, virginity, martial virtue, and regeneration is the job of the men' (Olujic 33-34). Peristiany asserts that honour and shame are socially evaluated attributes. Delaney elaborates why 'honour is typically a trait of men and shame a distinct attribute of women' (36). Akpinar argues that the 'hierarchical dichotomy' of male/female underlies the 'honour/ shame complex' (91).

Shiva states that raping the women of the opposite groups has been employed as a weapon to symbolically defeat the enemy. Shiva states that there are a number of incidents of women taking their own lives, jumping from the bridges or swallowing poison. Thousands of women embraced death at the hands of their men heroically to avoid sexual violence from rival communities (231). These incidents show that it was not a woman as person that mattered; it was rather the honour of the community or nation that mattered the most.

In the cultures where women's chastity is valued a lot, women feel obliged to sacrifice their lives to escape sexual violence and to maintain the honour of community. The women, who are raped or forcefully married and made to conceive, become polluted by the seeds of impure people. The "notion of respectability, the custodianship of culture, the purity of religion has come to rest on female body" (Jasbir 14).

The data for the present study was collected by interviewing forty female survivors of 1947 migration. The respondents were 13 years or above at the time of migration. The interviews were based on the narration in response to the request to narrate the most dreadful experience in respondents' migration journey. The audio recorded interviews were transliterated and translated in English for analysis. The interviews were numbered as $\mathrm{N}$ which stands for narrative in this paper with an addition of numeric digit from 1 to 40 to ensure anonymity of the respondents. Employing grounded theory data analysis techniques, the study followed a three-step coding method: (a) initial, (b) focused, and (c) theoretical (Charmaz 67). As the actual pronunciation did not matter, the data was presented by transliterating it in Roman script and giving English translation of each line. Only relevant examples have been given here from a data of forty narratives which is safe with the researcher in both the audio and written forms. The narrative number (e.g., N1) is given before different examples for the sake of clarity regarding the multiple sources the data were coming from. 'Transliteration' and 'translation' markings are given at line level i.e., with every line quoted in the paper.

It was found by locating the themes that the migration experience was 
life threatening as a whole and in some of the narratives more than one precarious incident was narrated. The data shows that the migration was not a voluntary movement but the Muslim community was forced to leave. Furthermore, the sorting out of the themes and axial coding resulted in locating the three main phases in the narratives: pre-eviction, eviction and the journey phase. The Preeviction phase includes the context which pushed Muslims to set out and, at its centre, the motivation for migration or the reasons for flight. The Eviction Phase was the phase during which the migrants actually had to leave their homes and villages. The Journey Phase deals with different dimensions of journey during which Muslims were travelling within Indian territories towards the border.

The different forms of violence faced by Muslims in the three phases of migration as witnessed by the narrators under study are as under:

Massacres and mass killing of Muslims in their houses, villages and camps

Sexual violence: Rape and abduction of Muslim women

Gendered violence: Chopping off the breasts of women, piercing the bellies of pregnant women and removal of fetuses from their bellies.

Infanticide: Piercing the bodies of Muslim children with swords and hanging them up on swords/daggers swirling them and throwing them away.

Annihilation of Muslims: Poisoned water in wells, canals and taps

The travelling people were forced to drop the small babies and infants in fields as it was a burden to carry them

Mass killing resulting in unburied dead bodies lying in streets, along the roads and in fields, decaying and stinking

The convoys and trains attacked and butchered.

A number of themes emerged as a result of the application of grounded theory on the data. However, this study considers the themes that are relevant to violence only. These themes and the narratives that included them are given phase-wise here: 
Table 1: Themes of violence in Phase 1 (Pre-eviction)

\begin{tabular}{|c|c|} 
Themes & Total Frequency \\
\hline $\begin{array}{c}\text { Attack or threat of an } \\
\text { attack by the Hindus or } \\
\text { Sikhs }\end{array}$ & 27 \\
& $\begin{array}{r}\text { (Found in N6,N7, N8, N9,N10,N12,N14, N } \\
17, \mathrm{~N} 19, \mathrm{~N} 20, \mathrm{~N} 21, \mathrm{~N} 22, \mathrm{~N} 23, \mathrm{~N} 24, \mathrm{~N} 25, \mathrm{~N} 2 \\
7, \mathrm{~N} 28, \mathrm{~N} 29, \mathrm{~N} 30, \mathrm{~N} 31, \mathrm{~N} 32, \mathrm{~N} 33, \mathrm{~N} 34, \\
\mathrm{~N} 36, \mathrm{~N} 37, \mathrm{~N} 39, \mathrm{~N} 40)\end{array}$ \\
\hline Mass Killing & 23 \\
& $\begin{array}{r}\text { (Found in N2, N4, N5, N6, N7, N11, N12, N } \\
13, \mathrm{~N} 14, \mathrm{~N} 17, \mathrm{~N} 18, \mathrm{~N} 19, \mathrm{~N} 21, \mathrm{~N} 22, \mathrm{~N} 24, \mathrm{~N} \\
27, \mathrm{~N} 29, \mathrm{~N} 31, \mathrm{~N} 32, \mathrm{~N} 34, \mathrm{~N} 35, \mathrm{~N} 36, \mathrm{~N} 37)\end{array}$ \\
\hline $\begin{array}{c}\text { Women under threat of } \\
\text { being kidnapped, suicid- } \\
\text { al attempts, murders of } \\
\text { women by family }\end{array}$ & $\begin{array}{r}\text { (Found in N2, N4, N5, N6, N11, N13, N17, } \\
\text { N18, N20, N12, N24, N25, N31, N32, N34, } \\
\mathrm{N33}, \mathrm{N} 36, \mathrm{~N} 37)\end{array}$ \\
\hline
\end{tabular}

Table 2: Themes of violence in Phase 2 (Eviction)

\begin{tabular}{|c|c|}
\hline Themes & Total Frequency \\
\hline Life threat/ mass killing & 10 \\
& $\begin{array}{r}\text { (Found in N2, N18, N24, N27, N28, N31, } \\
\text { N37, N38, N39, N40) }\end{array}$ \\
\hline Vulnerability of women & 05 \\
& (Found in N17, N20, N22, N24, N40) \\
\hline
\end{tabular}

Table 3: Themes of violence in Phase 3 (Journey)

\begin{tabular}{|c|c|} 
Themes & Total Frequency \\
\hline $\begin{array}{c}\text { Massacre or the threat of } \\
\text { massacre }\end{array}$ & 24 \\
& $\begin{array}{c}\text { (Found in N1, N2, N4, N5, N6, N7, N8, } \\
\text { N11, N12, N14, N15, N16, N20, N21, N23, } \\
\text { N27, N28, N30, N31, N32, N35, N37, N38, } \\
\text { N39) }\end{array}$ \\
\hline Looting and kidnapping & 18 \\
& $\begin{array}{c}\text { (Found in N1, N2, N3, N4, N5, N6, N11, } \\
\text { N14, N23, N24, N27, N28, N29, N30, N35, } \\
\text { N38, N39, N40) }\end{array}$ \\
\hline
\end{tabular}


The mass killing at phase one indicates the madness that occupied human minds around the partition of the subcontinent in 1947 and the resultant migration. The communities in clash developed a desire to launch a quick genocide and wipe out the others. In the context of this study ${ }^{1}$, the massacres of Muslims at the hands of Hindus and Sikhs show that their hatred had made it impossible for them to tolerate even a single Muslim in India. The mass killings not only ensured a decrease in Muslim population but also proved to be a push factor for the survivors to feel vulnerable and hurriedly leave those areas leading to the ethnic cleansing of the territory. The women were being robbed off their feminine identity by mutilation of their feminine organs leaving them with a stigmatized identity of a half woman in their future life. They were an easy target since they were too weak and confused to defend themselves. Here are a few examples from the narratives of migrant Muslim women. N6

Transliteration: chhaati kat rakhi thi sari lagaiyon ki

Translation: The breasts of all the women were chopped down

Transliteration:Youn lag rai thi talwarain galay kaat rai thi lagaion kay munh pay lag rai thi

Translation: The swords were hitting like this, cutting the throats of women, were hitting their faces

N11

Transliteration: Othay mar kutai horahi thi, aurtan ka kisi ka modha youn utar gaya kisi ka pet cheer diya

Translation: Killing and beating was going on there, one woman's shoulder was disjointed, the other had her belly cut

The excerpt from N17 reveals the fact that in general people were killed and chopped regardless of gender and age and no one was spared in these attacks. Even unborn babies were taken out by piercing their mother's womb and whirled on spears. It establishes the rival's identity as agents aiming at annihilation of enemy. Women were the main target of their atrocities. The emotional shock was used as the main strategy to overwhelm Muslims with a sense of insecurity. N17

Transliteration: Es tarha unhan ney katia na jis tarhaa pathey kati dey

Translation: They cut (the people) the way fodder is cut

Transliteration: Sab kat diya, aik na chhori uthey chadi

\footnotetext{
${ }^{1}$ As this study is based on the narratives of the Muslim women survivors, it carries only the Muslim perspective. However, similar incidents did happen to Hindu and Sikh women on the Pakistani side of the border.
} 
Translation: All were butchered, no girl was left there

Transliteration: Unhaan Ney estraha katyakay paet chey barcha mar kay hamla aurat da bacha nikaal kay barcha tey latka daindey see

Translation: They pierced the belly of pregnant woman with spears would take out the baby and hung it on spears

N27

Transliteration: Nand vi meri aa kay wahin qatal hui uskay andar say ojhh kad diya

Translation: My sister in law was also murdered when she reached there, (they) took out her intestines

These examples from N27 again show women as special victims. In fact there was no place for Muslims. Their whole community regardless of gender and age had become a victim of atrocities. An excerpt from N31 underscores the suffering of Muslims in general and parents in particular who were made to suffer the sight of destruction of their children. It also reveals their intent of ethnic cleansing by destroying the chances of regeneration of the enemy by killing their children and by ensuring the departure of maximum if not all the surviving Muslims. N31

Transliteration: Bachey tor tor kay khoh maan ghair kay tay oper tey aag lai khoh maan matti ka tail gair kay.

Translation: Children were snatched, were dropped into well and were set alight by spilling the keroseneoil in well.

The communal violence of Hindus was especially against women and children. Excerpt from N34 records the observation of sight of children hung on the spears by non Muslims and the killing of infants and children in huge number. N34

Transliteration: Bachey bohat marey jinhaan dey bachey godian see oo bohat marey

Translation: Children were killed in huge numbers, those who had infants, they (infants) died in huge numbers

Transliteration: Gaon mein aurtaan tay bachay boht thay

Translation: In the village the women and children were in great numbers

Transliteration: Mar dharh, jo Hindu they na unhon ney bandey bohat marey they

Translation: Killing and torturing, Hindus killed so many people

Transliteration: Zananian bhi mari bachey vi marey, trangliaan tey tang 
tang kay

Translation: Women were killed, and children too were killed, by hanging them on fork shaped sticks

The accounts given above show that women and children were given a fairly equal treatment as victims by non Muslims. The dead bodies were lying unattended as there was no one to give them a respectable burial. The excerpt below portray a situation where men and women embraced death together. N36

Transliteration: Unki jananian vi mari pari bandey vi marey parey

Translation: Their women and men were lying dead

The excerpt from N18 portrays a migrant who sacrificed her whole family; she calls them martyrs. According to her, Hindus not only killed Muslims but chopped their bodies and burnt them. They wanted to eradicate all the signs of their victim's existence. It was a way of asserting their authority and territorial hegemony. N18

Transliteration: Hamarey khandan mein koi nai bacha tha, mera tu sara khandan hi Hindion ney shaheed kar dia kat kay

Translation: No one was left alive in our family; my whole family was martyred by Hindus who butchered them

Transliteration: Fer marey baron key tu paer kat kay dhunwain mein rakhey they saran wastay

Translation: Then they placed the chopped feet of my elders in smoke to be burnt

The excerpt from N38 highlights how the women proved to be an easy target so there was mass killing of women folks. It was also symbolic in the sense that women are a source of reproduction and killing them and their children was a symbolic genocide of Muslims. N38

Transliteration: Fir Anbalay zila maan tu bari bachion kay youn bajar paray they

Translation: Then in district Anbala the streets were full of dead bodies of girls

The excerpt from N5 highlights that the Muslims in trains, caravans and even camps were not spared from kidnapping.

N5

Transliteration: Jonsi 4 chokrian uthai tagri, wo lay gaey ...

Translation: The four healthy girls which (they) kidnapped, they took 
away...

Transliteration: Bandoqan chalanday they, kamp pay bhi hamla hoya tha wahan bhi wahi mar khanch

Translation: They opened fire, the camp was also attacked and there too was the same killing and kidnapping

N27

Transliteration: Dunia fana kar di, gharon kay kunday khulwa khulwa kay koi nai chhadia

Translation: (They) ruined everything, they got the bolted door opened and spared none

Transliteration: Acha fer bolay bhi paen chod Muslay parey aan enhan maro pharo

Translation: Well, then they said, "sister fucker Muslims are lying here, kill them, arrest (them)"

Hindu rioters abused, and killed Muslim migrants and cut their body parts. N27 shows that there was Muslims' blood everywhere and it was mixed in canal water. N 11 described a similar situation. According to N28 at times they thought that they would not survive due to massive bloodshed. Hindus did not spare anyone. Even Hindu officials in the Military brutally killed and looted the victims. N28

Transliteration: Pher dandey maran admiyan ko bhi dangraan ko bhi aurtan ko bhi ye military waley

Translation: They, the military men, would beat men, cattle and women with sticks

The excerpt from N31 indicates that masses were murdered; even kids were killed mercilessly to torture the Muslim parents. The children lost their mothers in that hour of chaos. N32

Transliteration: bachiyan nu palian maan tangian, jawan, jawan bachian nu lay gaey

Translation: (They) hanged the children on spears; (they) took away young girls

Transliteration: Bachey aur admian par matti dali toya khod khod kay khud merey bhai nay

Translation: My own brother covered kids and men with soilafter digging pits

The excerpt from N 35 indicates how Muslims were targeted 
by Sikhs and Hindus. N31 also reported similar details. To tease and disgrace the Muslims, the attackers would abuse them and mention their female family members in humiliating terms to insult the Muslims. N35

Transliteration: Sikhaan ney hamla kita si, Hinduan nay golyan chalayan, barchay kadday gandassey wagaye boht nuqsan hoya

Translation: Sikhs attacked (us), Hindus fired shots, (they) used daggers and spears, there was a huge loss

Transliteration: Kehnda musslay nay saanu tii deni apni

Translation: He said, "the Muslim is going to hand his daughter over to us"

When Muslim men sensed their helplessness in protecting their women, they either killed their women or took oath from them to drown themselves or lick the poison in case they were likely to be assaulted by the non Muslims. This theme presents the reciprocal relationship of genders: the honourable men and honour bound women (Akpinar 91). Men were ready to sacrifice their lives to save the women, however, they must be protected from getting polluted by the external forces. The polluted women were a stigma for the community and a symbol of victory for enemy so the Muslim men preferred killing their women being pure rather than letting them get polluted and have a life with stigmatized identity.

Excerpt from N5 underlines the fact that the Muslim young girls were not safe even in the camps. Muslim camps were established for their stay as long as some means of transport were not arranged or a caravan was not formed. It portrays that there was no safe place for these women even when it was being managed by the government or military itself. N5

Transliteration: Aurtaan ko betheri ko kampan maan say utha kay lay gaey

Translation: They kidnapped many women from the camps

Excerpt from N6 throws light on the preference of migrants for sustaining the honour at the cost of their religious identity which was making them susceptible to loss of honour. Pretending to be Hindu was a guarantee of safety of family honour because the rioters would not attack the non-Muslims. N6

Transliteration: Hamari haweeli kay bech maan aik kunwan tha kunwen kay oper khari kar di, darwazay gate band kar diay

Translation: There was a well in our mansion, (they) made the women 
stand on well, doors and gates were closed

Transliteration: Baray baray darwajay thay hmary bhi jis wakhat sikh awan gaey maran, us waqt sarian nu kunwen chay gaer dawan gay Translation: We had big gates, so that if the Sikhs came to kill, (we) all (the women) would be thrown into the well

Transliteration: Hamari ijat rah jaway gi, fer hamara chacha tha boliya main Hindu ban janwa ga

Translation: Our honour will be preserved then our paternal uncle said that he will become a Hindu

Scores of women jumped into the wells to maintain their purity and to save their family honour. Two aunts of narrator of N11 also jumped into the well and justified their decision by saying that after all one had to die then why not die with grace. Excerpt from N13 underlines the fact that wells were filled with the women who jumped in the wells during the attack or under the threat of any likely attack. N 18 described the same details. N13

Transliteration: Fir Korwey maan hamla hoya na khoh bhar gaey thay Translation: Then Karwa (name of a Village) was attacked; wells were full of women

Transliteration: zananian mariyan khoh maan gir kar, khoh maan ap giriyan izat ki maariyan

Translation: Women died by jumping into the wells, they dropped themselves in the wells to safeguard their honour The excerpt from N24 focuses on the determination of Muslims that they would execute theirwomenbutwouldn'tallow enemiestotake them away.There werenumerous incidents where the young girls were thrown into the wells to avoid abduction. N24

Transliteration: Koi Sikh pakar kay na lay jawey koi beizati na ho jaey. Translation: Lest some Sikh should kidnap, lest you should be dishonoured

Transliteration: Kunwan mein geran gay, ay kahnada mera baap Translation: (We) will drop (girls) in the well, said my father

Transliteration: Lok rat nu bachiyan nu utha kay beth jandy bhi jis waqata esa moqa aey

Translation: People used to wake their girls up at night, fearing any such incident 
Transliteration: Hamla ho jaey apni bachiyan nu utha kay kunwen chey gaer dain

Translation: In case of assault, they could throwtheir girls into the well N30

Transliteration: Sada jera chacha see unhain sanu zehar day k na khoh day oper khara kar dita

Translation: Our uncle handed us poison and made us stand on well

Transliteration: kanda jad tanu chukan aye na hindu tay tusi kha lio

Translation: ... he said if Hindu came to kidnap us, we should eatthat

These passages portray women as absolute victims placed in a situation to choose between the devil and the deep sea. N31 gave the same details. N35 recounts how her brother asked them to jump into the well. It reinforces the men's position as decision makers, evaluators of the situation and having authority to command their women to act according to their orders.

There was no place for a stigmatized woman in the community. That's why once kidnapped, many women refused to come back to their families. The following quote from N32 shows the decision of the kidnapped women to submit to the Hindu custom of having tillak on forehead and her choice of remaining there even when the family was eager to bring her back. N32

Transliteration: ...2 bachian tay aai vi nai sharmandi kay ab ham kahan jaingi

Translation: ...two girls even did not come back out of shame that where would they go

Transliteration: Han Unhin kay han rah gai, unhan nay mathay pa til la rakhiya

Translation: Yes, they stayed at their (non Muslim's) place, they were wearing red marks on their forehead

The N36 highlights the fate of women who jumped first to save the honour and were buried, suffocated and died at the bottom of wells under the weight of women who jumped after them. Those who were at the top were able to survive and were taken out while the dead ones were left in the wells as no one had time to take them out and give them burial. N36

Transliteration: Jo oper thi wo nikal li jo nichay thi wo mar gai

Translation: Those who were on the surface were taken out and those who were at the bottom, passed away 
The theme of kidnapping throws light on the incidents of abduction of Muslim women and looting of the assets of uprooted Muslims. Kidnapping of the Muslim women is linked with the themes discussed earlier where Muslim men and women are reported making efforts to avoid the kidnapping at any imaginable cost like murdering their own women or women themselves committing suicide. N1

Transliteration: Dhian nu lay gaey, sohnian nu, jerian sohnian sanakhian onhan nu lay gaey

Translation: (They) took away the girls, the beautiful ones, those who were pretty, they(non-Muslims) took them along

The excerpt from $\mathrm{N} 1$ contains the information regarding the kidnapping of girls. The least attractive girls too were not spared. They had to pay for being Muslims and were killed. The excerpt from N5 shows that the healthy and strong girls were specifically targeted. N11 suggests that during the journey non-Muslims kept on attacking and looting. Muslims were left empty handed and helpless. The attackers took hold of jewellery from the dead bodies of women by cutting and piercing the body parts of deceased women. They were not ashamed of their brutality; rather they were doing so as their religious and ethnic obligation to teach Muslim migrants a lesson. The excerpt from N14 portrays the situation of sudden attack when the women initially could not find time and chance to escape kidnapping but later they were able to figure out the option of jumping into well and to escape dishonour. N14

Transliteration: Saat tiaan

Translation: (they, the abducted ones,) were seven (daughters)

Transliteration: Fer kunwain maan gir gayan tian

Translation: Then (the daughters) dropped themselves into the well Excerpt from N27 again highlights the dominant position of non Muslim men who chose to kidnap the healthy and strong Muslim girls only. N28, N34, N35, N38 and N39 and N40 contain the similar information. The helplessness and weak position of Muslim men and women is underlined here.

N27

Transliteration: Unhan lay gaey jeri sohni sohni zananian thi, tay kisi kay bachey thay na, saarian chant chant kay Hindu lay gay

Translation: They took away the pretty ones, and some of them had kids, they sorted out and took away all of them (beautiful girls) along Transliteration: Tay koi khoh maan gir gai, khoh bhar gay they zanainain 
kay

Translation: Some (of them) fell into the well and wells got filled with women

On the Indian side of the border, by doing all the above mentioned actions, the Hindus and Sikhs were establishing their supremacy and victory over Muslims by robbing them off their women and their honour. However, the emotion of revenge can also be one of the factors that had led the Indian rioters to commit violence against these migrants to Pakistan as the Sikh and Hindu migrants from Pakistan on their way to India were also receiving a similar violent treatment.

I will close the section of presentation of analysis with the following excerpt from N7 highlighting the height of plight of women and the extreme degree of disgrace caused by enemies:

Transliteration: Unhaan nay larkiyan nu tangiyan nal joriya tha nangiaan

kar kay kapray utar kay Mahrany day pula tay

Translation: They tied the girls with tongas (horse carts), after stripping them off, on the bridge of Mahrany

Transliteration: Unhaan nay bari buri kiti tauba tauba, eni behurmatti

kiti, oh aurtaan day haal kitay soch vi nai sakdy log

Translation: They behaved the worst, God forgives, caused a lot of dis-

grace, and treated the women the way people even cannot imagine

This excerpt not only highlights the helplessness of the maltreated women but the injured status of whole Muslim community as well. The disgrace of one female member was symbolically the humiliation of the whole community and the nation at large. Many of the narrators have given the description of violence which was directed on them for multiple times. They, at times, included the details of violence in other areas about which the men of their family told them. It is in agreement with Pandey's (74) observation that there was always violence out there.

Menon and Bhasin have discussed about the gendered aspect of formation of nation where women defined the boundaries between nation and communities during the partition (172). The non-Muslim men's role of being violators of peace and order, armed attackers, and villains is further highlighted. They were murderers (N1, N11, N14, N27, N28, N31, N32), kidnappers (N1, N5, N27, N32, N34, N35, N39, N40), bullies (N15, N35, N12), violent attackers (N5, N8, N14, N27, N28, N31), and they were threatening (N1, N8, N12, N14, N11) and hegemonic (N15, N5). They were choosy and selective in kidnapping the girls. Being a powerful group they enjoyed the right of selection of the victims according to their own standards of beauty even during 
a criminal activity. The language of the attackers is too offensive and hurts the feelings of victims (N27 \& N35). They were employing verbal tool to humiliate the weaker group as Menon and Bhasin have also stated in their research.

The non-Muslim rioters abducted (N5, N32) and tortured the women (N31, N32). They have been piercing and swirling the bodies of their children and butchering the women mercilessly. Pandey has pointed out the same that both women and children are often victims once they are exposed to the communal violence. The theme of mass killing demonstrates the violence directed on Muslims particularly on women who were being targeted to be victimized (61). N6, N12, N17, N27, N37 portray them as target of communal violence as observed by Menon and Bhasin (57). Besides women, the children also prove to be easy victims of communal violence as the excerpts from N31, N32 and N34 show, in line with the findings of Pandey (77). The men are not portrayed to be any more in a position to defend or protect the women. There are references to the dead bodies and murder of both the genders and the burial of multiple dead bodies in one shallow pit. The theme of women under the threat of being kidnapped is a very critical theme. It was not just a physical threat of losing life. It included the threat of loss of family honour as the women symbolize the honour of the family. Menon and Basin (94) have observed that the women underwent the worst forms of violence including rape, kidnapping, mutilation and imprinting of religious symbols. The position of women in this theme is constructed in line with the Menon and Bhasin's findings (94). Women on one hand were weak and needed protection and would panic in the absence of male protectors. On the other hand, they have been fearlessly sacrificing their lives to preserve their individual and family honour. There is a cycle of threats and the possible culturally approved responses both on the part of Muslim men and women. The women not only had the status of honour bearers but also the protectors of family honour. At the same time, as opposed to the protector, the threat to family honour is also associated with the women. Men are insecure and dependent on women for maintaining the family honour for which, according to Menon and Bhasin (103), they have been causing violence including poisoning, and assassinating their own women. Women embraced that duty as much heroically as men had been protecting them at the risk of their lives.

The violent enemies are defeated by the women at this war front contrary to their physical encounter with Muslim men. This is the demonstration of group resistance to agonizing oppression. Being physically weak, they could not reciprocate the assaults, a resistant attitude to them in practical sense of the term, however, they did not surrender either. These narratives expose the ways in which 
Muslim women lived, responded and resisted to boundary formation between two nations at larger level and communities at local level (Menon and Bhasin 105).

It was not only the young women but the old women too were made to stand on the well for the whole night to be pushed into it in case there was an attack. The women who were protected at the risk of life were being sacrificed for an abstraction i.e. honour. Cockburn (58) has discussed female figure as a symbol of nation. The assault on women was equivalent to the assault on the whole nation. The consciousness and pressure to maintain the honour was already there in the society. The changed social scenario made this response emerge at the time of crisis. Women stand as the representatives of purity of the nation as highlighted by Mayer so an attack on the women is a symbolic attack on men and nation at large (65). The war time gendered violence is a demonstration of social dynamics which already exist in the society as has been discussed by Maria Olujic. Daphne asserts that women are the representatives of the family honour (41). Olujic has pointed out that the concept of women being the honour bearers is strictly tied to their sexuality and the honour of the women is protected by the men through strict control of their chastity and virginity (44). The role of Muslim women in maintaining the honour norms in society as revealed in the recorded narratives is highly confirmatory to establish their status as preservers of the honour.

N11, N13, N18, N31, N34, N35, N36 portray the women volunteering to jump into the wells. They sacrificed their lives for the sake of honour to avoid any likely threat to their honour resulting in the disgrace of the whole nation as discussed by Feldman (66) and Sonu Shiva (232). Butalia (97) has mentioned a well in a village which overflowed with women. My respondents have also stated a similar situation. The narrator of N27 shares her opinion saying whosoever had some sense of shame, jumped into the wells to avoid disgrace. Shiva (232) has discussed jumping into the well as a cause of most women's death at the time of partition. Men could make up their loss of property but women could never recover their loss of dignity which is strictly tied with their sexuality.

The excerpts from N6, N24, N25, N32, N35 throw light on the cost of boundary formation paid by women by describing about the most approved and frequent decision of men pushing their women into wells to prevent their kidnap and rape because the regulation of sexuality of women was at risk as pointed out by Butalia (98) and Jasbir (22).

The details match and supplement the data available on maltreatment of women of other communities as discussed by Veena Das (72). The respondents frequently talked about the murders and kidnapping of Muslim women. 
They proudly narrated about their being willing to ingest the poison or jump in the wells and some of them narrated their own account of jumping in the wells. They did not talk about their feelings or fear before jumping into wells or when they were sitting in the wells. The reason behind this narrative strategy is the cultural approval of the act of sacrifice of life for the preservation of family honour. They maintain their heroic status by avoiding saying anything which may label them as timid or less loyal to their religion, nation, and community. The study has explored 40 personally collected narratives of female survivors of 1947 migration from East to West Punjab for the different forms of violence directed towards the Muslims by the partition rioters in newly formed India. It was found that violence prevailed everywhere and was experienced by the migrants at physical, psychological and emotional level throughout their experience of up-rootedness. The culturally specific practices put the abstraction of honour at the forefront as it had to be maintained even at the cost of the lives of the women. Historically and culturally, the mutilation, rape and kidnapping of the women stood for the disgrace of the whole community. It was found that the Indian Muslim community was conscious of maintaining their honour and purity by normalizing the killing of women by the male members of their own families and by women themselves volunteering to jump into the wells or ingest the poison in case of assault. 


\section{Works Cited}

Akpinar, Aylin. "The Honour/Shame Complex Revisited:Violence Against Women in the Migration Context." Women's Studies International Forum. 26.5. (2003). Print

Andrews, Tom. "What is social constructionism." Grounded Theory Review. 11.1 (2012): 39-46. Print.

Bourdieu, Pierre. "Theory of Symbolic Power." Culture/Power/History: A Reader in Contemporary Social Theory. 155 (1994). Print.

Brown, Scott C., et al. "Exploring Complex Phenomena: Grounded Theory in Student Affairs Research.” Journal of College Student Development 43.2 (2002): 173-183. Print.

Burr, Vivien. Social Constructionism. Routledge: Taylor and Francis. 2nd. 2003. Print.

Butalia, Urvashi. The Other Side of Silence:Voices from the Partition of India. Penguin UK, 2017. Print.

Chamberlain, Mary. "Rethinking Caribbean Families: Extending the Links." Community,Work \& Family 6.1 (2003): 63-76. Digital.

Charmaz, Kathy. Constructing Grounded Theory: A Practical Guide Through Qualitative Analysis. Sage, 2006. Print.

Cockburn, Cynthia. The Space Between us: Negotiating Gender and National Identities in Conflict. Zed Books, 1998.

Daphne, Jeremy. "A New Masculine Identity: Gender Awareness Raising for Men.” Agenda 14.37 (1998): 24-29. Digital.

Das, Veena. "Language and Body: Transactions in the Construction of Pain." Daedalus 125.1 (1996): 67-91. Digital.

Das, Veena. Life and Words:Violence and the Descent into the Ordinary. U of California P, 2006. Print.

Delaney, Carol. "Seeds of Honour, Fields of Shame." Honour and Shame and the Unity of the Mediterranean 15 (1987): 35-48. Digital.

Douglas, Mary. Purity and Danger:An Analysis of the Concepts of Pollution and Taboo. London: Ark 1966. Print.

Feldman, Shelley. "Shame and honour: The Violence of Gendered Norms under Conditions of Global Crisis." Women's Studies International Forum 33. 4 (2010): Pergamon, Digital.

Gill, Aisha. "Voicing the Silent Fear: South Asian Women's Experiences of Domestic Violence." The Howard Journal of Criminal Justice 43.5 (2004): 
465-483. Digital.

Glaser, Barney G., and Anselm L. Strauss. Discovery of Grounded Theory: Strategies for Qualitative Research. Routledge, 2017. Print.

Glaser, Barney. "Theoretical Sensitivity." Advances in the Methodology of Grounded Theory. Sociology Press, 1978. Print.

Goddard, Victoria. "Honour and Shame: the Control of Women's Sexuality and Group Identity in Naples." The Cultural Construction of Sexuality. Routledge, 2013. 178-204. Digital.

Jain, Jasbir. Reading Partition, Living Partition. Rawat Pubns, 2007. Print. Kleinman, Arthur, et al., eds. Social Suffering. U of California P, 1997. Print. Mayer, Vicki. "Capturing Cultural Identity/Creating Community: A Grassroots Video Project in San Antonio, Texas." International Journal of Cultural Studies 3.1 (2000): 57-78. Digital.

Menon, Ritu, and Kamla Bhasin. "Recovery, Rupture, Resistance: Indian State and Abduction of Women During Partition." Economic and PoliticalWeekly (1993): WS2-WS11. Digital.

Menon, Ritu, and Kamla Bhasin. Borders \& Boundaries:Women in India's Partition. Rutgers UP, 1998. Print.

Morse, Janice M. "Situating Grounded Theory within Qualitative Inquiry." Using Grounded Theory in Nursing (2001): 1-15. Print.

Olujic, Maria B. "Embodiment of Terror: Gendered Violence in Peacetime and Wartime in Croatia and Bosnia Herzegovina." Medical Anthropology Quarterly 12.1 (1998): 31-50. Print.

Pandey, Gyanendra. Remembering Partition:Violence, Nationalism and History in India. Cambridge UP, 2001. Print.

Péristiany, Jean G., and John George Peristiany, eds. Honour and Shame: The Values of Mediterranean Society. U of Chicago P, 1974. Print.

Shiva, Sonu. "The Question of Healing and Forgetting: Disturbing Realities in Short Stories of Ritu Menon and Uravashi Bhutalia.” Cultural and Religious Studies 3.5 (2015): 227-234. Digital.

Strauss, Anselm, and Juliet Corbin. Basics of Qualitative Research Techniques. Thousand Oaks, CA: Sage Publications, 1998. Print.

---. Grounded Theory in Practice. Sage, 1997. Print.

Virdee, Pippa. "Negotiating the Past: Journey Through Muslim Women's Experience of Partition and Resettlement in Pakistan." Cultural and Social History 6.4 (2009): 467-483. Print. 